Article

\title{
Pastoral Stone Enclosures as Biological Cultural Heritage: Galician and Cornish Examples of Community Conservation
}

\author{
Richard Grove $^{1}$, Joám Evans Pim ${ }^{2}$, Miguel Serrano ${ }^{3}{ }^{\mathbb{D}}$, Diego Cidrás ${ }^{4} \mathbb{C}$, Heather Viles ${ }^{1}$ \\ and Patricia Sanmartín $1,5, *$ (D) \\ 1 School of Geography and the Environment, University of Oxford, South Parks Road, Oxford OX1 3QY, UK; \\ richard.grove@stx.ox.ac.uk (R.G.); heather.viles@ouce.ox.ac.uk (H.V.) \\ 2 Fundação Montescola and Frojám Commons Community, 15212 Lousame, Galicia, Spain; \\ info@montescola.org \\ 3 Department of Botany, Faculty of Pharmacy, University of Santiago de Compostela, \\ 15782 Santiago de Compostela, Galiza, Spain; miguel.serrano@usc.es \\ 4 Department of Geography, University of Santiago de Compostela, Praza da Universidade 1, \\ 15703 Santiago de Compostela, Galicia, Spain; diego.cidras.fernandez@usc.es \\ 5 Departamento de Edafoloxía e Química Agrícola, Facultade de Farmacia, Universidade de Santiago de \\ Compostela, 15782 Santiago de Compostela, Spain \\ * Correspondence: patricia.sanmartin@usc.es; Tel.: +34-881-814-984
}

Received: 25 November 2019; Accepted: 23 December 2019; Published: 2 January 2020

check for updates

\begin{abstract}
The role and importance of a built structure are closely related to the surrounding area, with interest in a given area having a concomitant effect on the relevance given to the constructions it may hold. Heritage interest in landscape areas has grown in recent times leading to a sound valorisation process. This connects with the recent concept of biological cultural heritage $(\mathrm{BCH})$, or biocultural heritage (definition still in process), that can be understood as domesticated landscapes resulting from long-term biological and social relationships. Although pastoral enclosures (in large part dry-stone walling, whose construction has been recognised by UNESCO as Intangible Cultural Heritage of Humanity since 2018) arise as traditional rural constructions linked with a way of life already disappearing, engaged local communities are recovering their biocultural value in terms of identity and positive conservation outcomes. In this sense, this article focuses on valuing traditional stone-built pastoral enclosures in two locations on the Atlantic coast of western Europe: Frojám (NW Iberian Peninsula) and Ladydown Moor (SW England). Findings concerning plant communities related to current or ancient pastoralism, and artefacts of built heritage are described, and an emphasis is placed on community engagement as a mechanism for conservation. The resilience of species-rich grassland communities is identified as a manifestation of biocultural heritage and an opportunity for habitat restoration. Finally, current trends and improvements in understanding of biological heritage and community conservation are addressed.
\end{abstract}

Keywords: pastoral enclosures; vernacular architecture; minor rural buildings; art of dry-stone walling; indigenous and community conserved areas; Galicia; Cornwall; forestry heritage; heathland and grassland conservation; plant biodiversity

\section{Introduction}

This study examines two areas where long-established land management practices have been disrupted during the last century as a result of technological or demographic change, bringing to an end, long histories of pastoralism. These changes are typified by agricultural mechanisation and 
its associated rural depopulation in Cornwall, and by a population shift to urbanised industrial employment in Frojám (Galicia), following government-led land seizures, and a fast rise and decline of mining in the area. However, the 'flight to the city' has recently reversed with increasing movement to a rural lifestyle under the guise of sustainability and quality of life, thus imposing renewed changes on abandoned landscapes [1]. In this sense, there is an increasing recognition of cultural values when discussing wellbeing in rural areas [2].

The concept of biological cultural heritage (or biocultural heritage), sometimes shortened to $\mathrm{BCH}$, is a very recent development. Ove Eriksson [3] raised a tentative definition of it in 2018 as the "biological manifestations of culture, reflecting indirect or intentional effects, or domesticated landscapes, resulting from historical human niche construction". In 2019, Lindholm and Ekblom [4] framed the concept as one that allows new approaches to heritage, nature conservation, landscape planning and management, thus defined as "an understanding of cultural landscapes as the result of long-term biological and social relationships, shaping the biological and material features of the landscape and also memory, experience, and knowledge". In practice, this can manifest in a variety of landscape features and ecological systems; each with distinct indicator species, archaeological deposits, and cultural associations.

The $\mathrm{BCH}$ concept is a relatively new and developing framework, where the biological makeup of the heritage site exists as a cultural indicator in its own right, in addition to the structures and deposits of archaeology and heritage. It originated from human intervention and endures beyond the life and preservation of any structures and activities linked to their origin. In this way, BCH represents a heritage perspective that specifically and uniquely attests to living artefacts as a complex system.

This article introduces a type of $\mathrm{BCH}$ overlooked so far, viz. stone-built pastoral enclosures, and introduces case studies in two territories on the Atlantic coast of western Europe (Figure 1) currently involved in endogenous processes of biological conservation and investigates parallels between the two. Using historical parallels of mixed pastoralism as a starting point, the study focuses on two zones of archaeological interest, assessing the establishment of functional stone-built livestock enclosures as indicators of local tradition. The paper goes on to look at how long-established and recently abandoned pastoral activities in these enclosures have manifested specific changes in local plant communities, leaving an adapted and indicative biological culture in their place. The first site, Frojám (or Froxán, Figure 1) is an Indigenous and Community Conserved Area (ICCA) in Galicia (Spain, NW Iberian Peninsula). In contrast with state-driven protected areas that often marginalised human communities living and interacting with rural spaces in traditional forms, ICCAs have emphasised the relevance of indigenous communities in the management and conservation of biodiversity [5] and biocultural heritage. Thus, this represents a paradigm shift from conventional approaches to the conservation of protected areas by recognising customary practices in the conservation of biological and cultural diversity [6]. The second case study, Ladydown Moor, St. Breward (or St. Bruwerd, Figure 1), in Cornwall (SW England), is also conserved by community and voluntary groups under the provisions of the Commons Act (2006) and the Countryside Rights of Way Act (2000), though ownership of parts of the area are now unclear [7]. Under this joint legislative protection, locals are granted rights of grazing and access to the traditional land holdings on the moor and are encouraged to be part of the decision-making process for aesthetic and management changes via local government-led initiatives [8]. Frojám and Ladydown areas share relatively similar ecological conditions, which make them comparable systems from the environmental perspective. The geological substrate in both cases is granite, over which siliceous acidic soils have developed $[9,10]$. Coastal Galicia and Cornwall belong to the same biogeographical unit, the European Atlantic province [11]; a wide region including the western European regions from northern Portugal to southern Norway and encompassing the entire British Isles.

More apposite however, the temperate hyperoceanic bioclimate existing in the areas of study has a reduced distribution in Europe, restricted to Ireland and narrow Atlantic fringes in north-western Iberian Peninsula, Brittany, and Great Britain [12]. This bioclimate is characterized by constant moisture 
and mild temperature, with a short annual thermic interval $\left(<11^{\circ} \mathrm{C}\right)[13,14]$. In the case of Galicia, the hyperoceanic climate is represented by a Submediterranean variant, with a perceptible fall in precipitation during the summer. The area of the Frojám enclosure lies in the Barbança mountain range at $500 \mathrm{~m}$ AOD (above ordnance datum), and summer drought is mitigated due to altitudinal compensation of water inputs [15]. This pattern of dry summers is historically reflected in Cornwall, although in recent years there has been a noticeable increase in summer rainfall, leading to a disruption in traditional farming practices on the peninsula [16].

In addition to historic cultural practices, the combination of climate and soil is a key determining factor for vegetation, being similar in lowland and submontane areas of the north-western Iberian Peninsula and south-western Great Britain. Forests are dominated by Oak woodlands (Quercus robur) with birch (Betula alba) and other acidophile species [17,18]. Interestingly, the grassland vegetation of pastureland in submontane-montane coastal Galicia (mesotemperate and lower supratemperate belts) and Cornwall have been grouped in the Violion caninae phytosociological alliance [19]. It is classified in the Class Nardetea, and so it is considered a priority for conservation European habitat (European code *6230) [20], in spite of the reduced occurrence of Nardus stricta in both areas [19]. This community was named Agrostis curtisii grasslands by Rodwell [21] and is dominated by Agrostis capillaris, Agrostis curtisii, Danthonia decumbens, and Avenula sulcata.

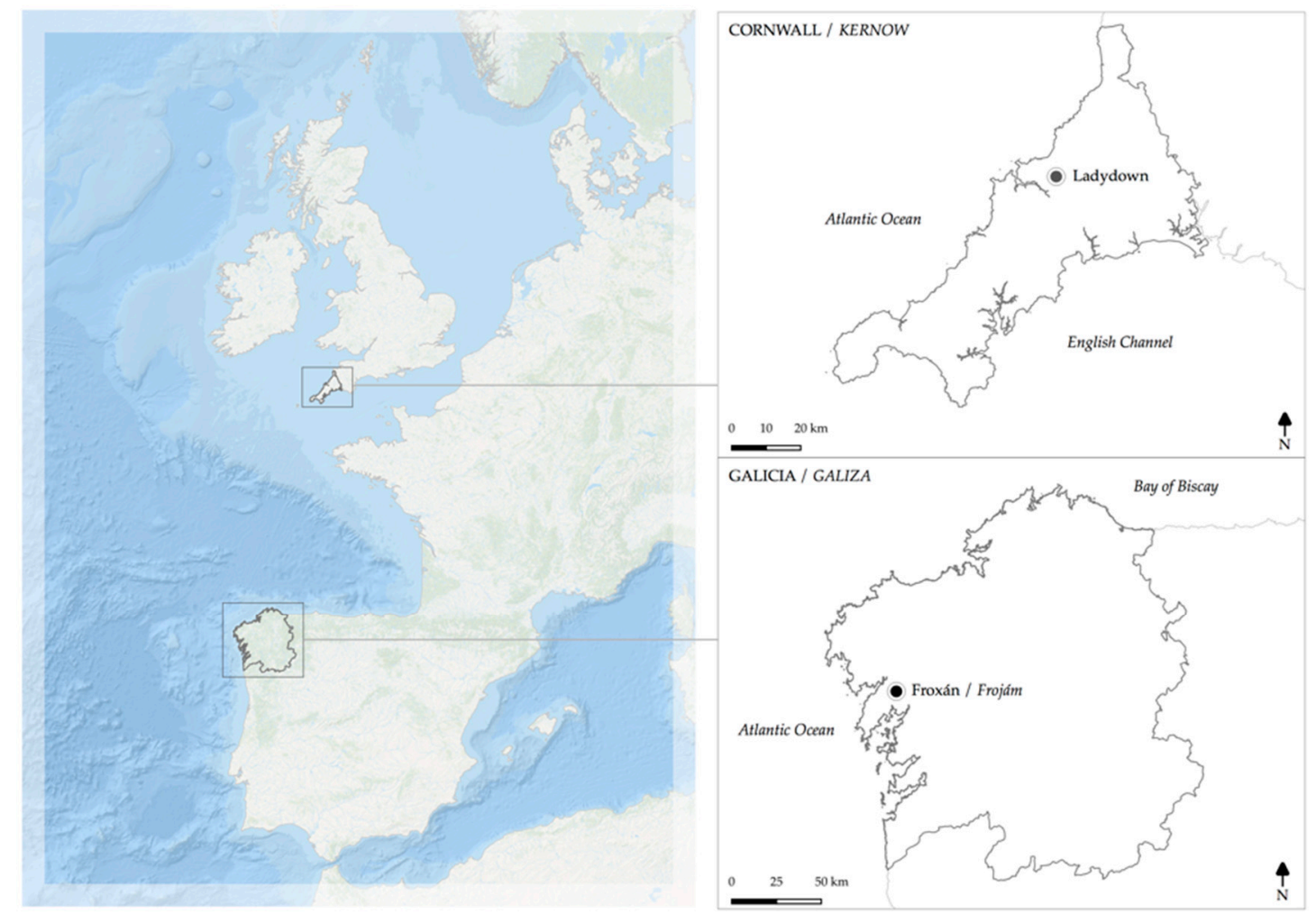

Figure 1. Location of the case-study areas.

In moist, acidic peaty soils in both regions, vegetation originally developed as wet heaths and bogs with Calluna vulgaris, Erica tetralix, and Erica ciliaris, in a mosaic with Sphagnum and Cyperaceae/Poaceae wet grassland communities. This type of mixed formation has been reconstructed through the Holocene with pollen data and plant macrofossils in peatlands of north-western Iberia and south-western Great Britain [22,23]. Plant macrofossils allow a good reconstruction of the local vegetation at different temporal layers, and when this information is combined with information from charcoal remains the prevailing communities can be identified in relation to putatively anthropic burning [24]. Although the resulting vegetation is a product of complex interactions dependent on local historic processes, continued grazing in enclosures should have led to the replacement of healthy vegetation and the 
expansion of pre-existing grassland communities, dominated by Molinia caerulea in the wettest parts [25]. Nevertheless, the process of vegetation turnover in heathlands is complex and can differ significantly between regions. Whereas in Galicia, Molinia caerulea, and Agrostis curstisii grassland have been historically a relevant constituent of peatland and wet heath systems [23], vegetation reconstruction in some British moors do not follow this pattern and peatlands have revealed a late relevance of Molinia caerulea, with a clear prevalence only after the industrial revolution [26]. Therefore, agents other than traditional grazing and burning have to be invoked as responsible, like increased atmospheric input and/or changes in grazing pressure [25]. However, vegetation in historical pastoral enclosures is inferred to have arisen from the effects of routine domestic herbivory over centuries, coupled with practices historically associated with pastures, moorland, and heathlands to maintain these ecosystems, such as burning [27]. Species turnover due to customary grazing and mechanisms of the new dominant species to endure after grazing abandonment has been described in the acidic grassland species Brachypodium pinnatum in Western Pyrenees [28]. In the same way, an analysis of British grasslands showed that the seed bank was dominated by propagules of species associated with eutrophic grasslands, so vegetation change would prove difficult to reverse [29]; however, this pasture endurance through seed bank dominance seems more related to improved grasslands than to unimproved grasslands. These descriptions of historical and environmental processes affecting the Ladydown and Frojám enclosures, as well as the composition of plant communities currently occurring, therefore allows for the determination of biocultural heritage artefacts within these zones as indicators of traditional activity in their own right. The further impact of community engagement as a mechanism for conservation of these rural assets in Galicia and Cornwall was analysed and compared in this study.

The main purpose of this article is to value the stone-built pastoral enclosures, analysing dimensions, materials, and construction technologies, and their influence in the current habitats and plant biodiversity, and the image of landscape, this analysis will occur within a framework of nature conservation, landscape planning, and management and heritage preservation on the basis of long-term biological and cultural relationships between people and their surroundings.

\section{Pastoral Stone Enclosures: A Biological Cultural Heritage}

Pastoral stone enclosures in Atlantic Europe were already common in the Bronze Age. Although many such enclosures served the immediate agropastoral needs of a given community, others likely had additional functions as central facilities for surrounding communities both for tending and controlling livestock (e.g., culling, marking, shearing, and safeguarding from predators) and as places of ritualized gatherings, public hearings common ceremonies, and trade [30]. Being coeval with Bronze and Iron Age hilltop enclosures in Galicia and Britain, some early enclosures possibly served simultaneous or shifting agropastoral-defensive functions while other were obviously too large (i.e., $>40$ ha) to perform military functions [31] but occasionally included hillfort features such as ditches and present evidence of human occupation such as small huts or chouços (where shepherds or cattle could shelter) or permanent settlements as in the 'banjo' type enclosures of the British Middle Iron Age [32,33].

In Cornwall and neighbouring Devon, Iron Age pastoral enclosures are exemplified by those of the Dartmoor area (30U 436281 5602042, datum WGS84) concentrated on the south side of the moor, usually on south-facing slopes above river valleys close to a water supply, according to Cunliffe [34]. In this area, Shaugh Moor (30U 426212 5588925, datum WGS84) is an interesting example that includes pastoral enclosures, burial cairns, and stone-walled huts, with evidence of continuous use from the second millennium BCE to the 9th century CE [35].

In more general terms, the settlement and enclosure of the Cornish peninsula are in contrast to the counties of Devon, Dorset, and Somerset. The pattern of grouped field systems with scattered farmsteads has endured in this region to a greater extent, where inland (in more intensively farmed and populated areas) the village became the de-facto settlement type [36]. Post-medieval enclosure in Cornwall can also have been said to progress at a reduced rate and lesser extent to other areas of 
England and Wales, with a significant percentage of tillable land structured and enclosed by the 17 th Century [37] with the retention of these forms to a greater extent than counties to the east, where later parliamentary enclosure is the dominant driver of extant agricultural landscape formation.

In Galicia, although agropastoral structures (e.g., enclosures, walls, and huts) have received little archaeological attention, recent finds in the Barbança mountain range [38-40], in the proximities of the Frojám site, have revealed not only their abundance but also their continued use over millennia. As in Cornwall, the spatial distribution of these structures is often conditioned by existing sources of fresh water and adequate orography [40]. Erected through dry stone gathered in the surroundings, enclosures often feature remains of huts or other types of shelters within their perimeter or built into the outer walls, built to the height of a person [39].

\subsection{The Frojám Enclosure as a Case Study in Galicia}

Located in the proximity of the Barbança mountain range where similar structures have already been documented [38-40], the Frojám enclosure stands out for its large dimensions. The granite dry-stone walls (whose construction is UNESCO Intangible Cultural Heritage of Humanity since 2018) are at the top of the Gironha mountain (29T 515908 4733504, datum WGS84) at altitudes ranging between 450 and $500 \mathrm{~m}$, and have two discernible sections (Figure 2). The first and larger section has a perimeter of approximately $1 \mathrm{~km}$ enclosing 5 ha of land while a second smaller enclosure is formed through an additional $500 \mathrm{~m}$ stretch of wall encircles an additional $2.5 \mathrm{ha}$. The enclosure lies within the customary lands of the Frojám Commons ('monte vizinhal em mão comum') that currently stretch over 100 ha, not serving as a boundary demarcation of any kind, with only the southern tip of the perimeter touching the community boundary at a vertex.

The larger and perhaps older enclosure has a slightly triangular shape with rounded edges, following the natural orography, with a spring ('Fonte de Ramo Curvo') at its northern tip that was likely modified to serve as a watering hole for livestock (Figure 2). The smaller enclosed area to the south (Figure 2) surrounds a peat wetland called 'Campo de Lamas' (literally, 'mud field'). Although signs of collapse and buried sections indicate a greater original height, most sections currently above ground do not exceed $0.5 \mathrm{~m}$ from the surrounding ground surface, making it difficult to discern from the taller scrub. Compared to its immediate surroundings abundant in granite outcrops, the enclosed area presents deeper soils which, together with access to water supply, seems to be the rationale behind the choice of the perimeter. This could relate to the availability of pastures during the drier seasons but perhaps also to the use of the area as a 'seara' (communal open field, used for the cultivation of rye or wheat in winter and spring) which kept livestock out of the enclosed area.

Several hypotheses have been raised [15] to account for the enclosure's unusually large dimensions compared to other known Galician examples. Placed at the watershed divide between the Ulha and Tambre river basins, the site could have hosted a seasonal inter-community livestock fair, a possibility hinted by existing oral lore that identifies Gironha as a place of annual assembly for supernatural beings. Alternatively, as suggested, the enclosure could have served to keep the community flock concentrated in the area with the most abundant pastures during the summer while keeping them out during the period of cultivation of winter grains. 


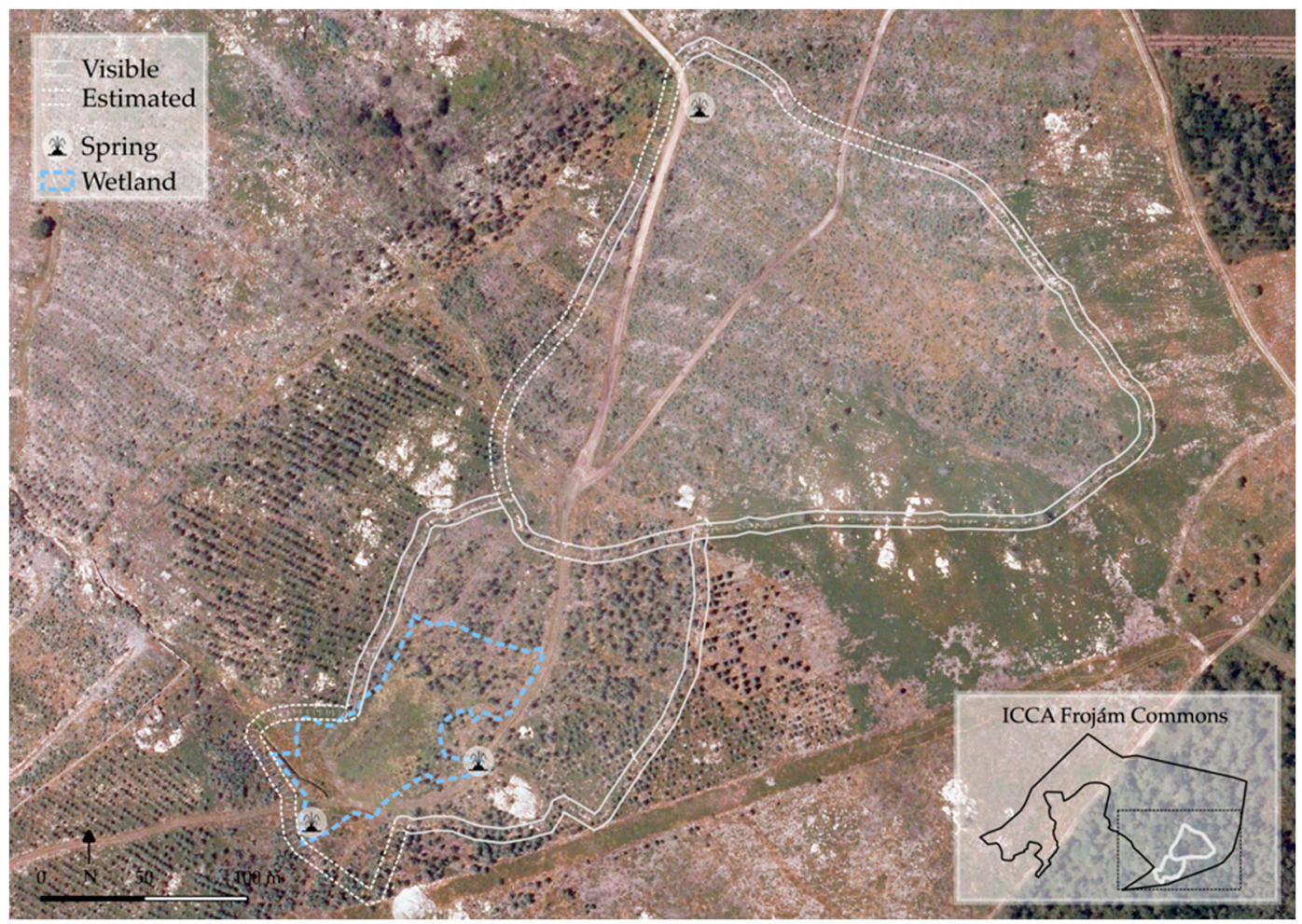

Figure 2. Orthoimage highlighting visible and probable sections of the Frojám enclosure. Based on IGN PNOA (Plan Nacional de Ortofotografía Aérea) 2008 images taken after the 2006 forest fires.

In spite of its dimensions, it was only during mechanical clearance made prior to a tree plantation in 2016 that a section of the enclosure was first noticed by community members (Figure 3). Although the local community is intimately familiar with its ancestral lands in which pastoralism endured until forced common land seizures in the 1940s, the structure had gone unnoticed. Orthoimages taken in 2008 (after forest fires in 2006) revealed the extent of the enclosure (Figure 2) and in 2017, after a preliminary archaeological field visit, a request was made for listing the site as protected heritage. Since its discovery, the local community has remained committed to preserving the site as part of its larger conservation efforts. This commitment has materialized through the natural beaconing of cleared wall sections and the incorporation of the enclosure in a conservation plan issued to restore the adjacent peat wetland [15]. While the ongoing wetland restoration process serves both biodiversity targets and community adaptation to climate change (by regulating water supply), the recovery of the enclosure is part of the community's reconnection with its pastoralist past.

Although the village itself is certainly older, Frojám appears for the first time in written records in a 1409 manorial agreement that set a rent to be paid in bread. The importance of pastoralism is evidenced in a 1527 manorial deed, were the annual collective rent to be paid to the feudal lord includes 'a good ram and two goat kids' ("un buen carnero et dos cabritos"), in addition to a rent to be paid in rye. Two centuries later, a renovated 1709 manorial deed established the obligation to serve two rams and three goat kids to the Marquises of Mos together with other goods that continued to be delivered annually by the commoners in Pedra d'Ouro, Noia. This deed also described the precise perimeter of the community's territory through various landmarks, including the 'Lage da Pedra Vigia', a large granite outcrop by the 'Campo de Lamas' peat area that also serves as a southern vertex for the enclosure. This microtoponym (literally 'Watchers Stone') at a place that would allow for the control of the enclosed area perhaps refers to its ancestral pastoral use.

As presented in Table 1, in the 1753 Marquis of Ensenada census, conducted across the Crown of Castille, Frojám appears with eight households, all of which kept livestock that included sheep, rams, goats, bucks, cows ( 2 or 3 per household and a similar number of calves), mares, mules, and pigs 
(either exclusively owned or in a form of joint ownership called 'parceria'). A total of 1753 livestock (188 heads, excluding stabled cattle and mules) are reflected illustrating the community's pastoral load at a time in which the enclosure may have still been in use; lack of living memory and state of conservation indicate abandonment prior to the 20th century.

Table 1. Livestock per household in Frojám according to the 1753 census ${ }^{1}$.

\begin{tabular}{ccccccc}
\hline Commoner & Sheep & Rams & Goats & Bucks & Mares & Total \\
\hline Domingo Devesa & 7 & 7 & 20 & 2 & 1 & 37 \\
Esteban da Costa & 10 & 1 & 14 & 1 & - & 26 \\
Francisco de Albagueira & 5 & 2 & - & - & - & 7 \\
Joseph San Lois & 5 & 2 & 13 & - & - & 20 \\
Lázaro Romero & 19 & 7 & - & - & 1 & 27 \\
Lucas da Costa & 14 & 4 & 2 & - & - & 20 \\
Manuel Romero & 6 & 3 & 5 & - & - & 14 \\
Thomas Cao & 22 & 9 & - & 4 & 2 & 37 \\
TOTAL & 88 & 35 & 54 & 7 & 4 & 188
\end{tabular}

${ }^{1}$ Arquivo do Reino de Galicia 2881 and 2882 Expediente do Catastro de Ensenada de Santa Eulalia de Vilacoba.

Manorial obligations (codified through 'foros') were sustained in Frojám until 1928 when villagers extinguished feudal ties with the Viscounts of São Alberto in exchange for a monetary payment of 6049 pesetas [41]. This meant that for the first time in centuries, villagers fully owned their smallholdings and common lands, but for the latter, ownership would prove to be short-lived. In fact, traditional pastoralist practices ended abruptly in Frojám in the 1940s with the usurpation of the village's common lands by the State forest services (Patrimonio Forestal del Estado), a phenomenon occurring throughout Galicia at the time.

The oldest villagers, now almost in their 100s, recall how before land seizures each of the village's households (four at the time) had a flock of 30 to 60 sheep and goats-mostly sheep-that were taken up to graze year-round in the commons. In 1940, the joint flock numbers essentially match the recorded 18th century load, perhaps indicating an ecological equilibrium. Oral memory matches existing 20th century records, as in the 1905 partition deed of Pedro Cau Boullón (a descendant of Thomas Cao) that left 15 sheep (valued 60 pesetas) and 20 goats (valued 100 pesetas) to his heir, the exact same number of heads his ancestor had in 1753.

The flock was shepherded up in the mornings and brought back at night-a task usually undertaken by children and adolescents-but remained to its own avail during the day as wolves and other predators did not appear to represent a significant threat. As the joint flock of roughly 200 head would stay together, and every village house had its own earmark that served to identify ownership of individual animals in case of doubt-although sheep are said to have headed back to their respective 'homes' without guidance.

Franco's regime forcibly turned the Galician village commons into productive forest monocultures, ending this age-old agropastoral system [42]. The first pine plantations were carried out in Frojám and neighbouring commons in 1947 in spite of fierce opposition and contestation-a total 389 ha of Maritime Pine (Pinus pinaster) and Monterey Pine (Pinus radiata) were planted in the late 1940s. Heavy fines were levied to those caught taking their flock to mountain pastures now riddled with newly planted pine trees. Although forest services designated a steep and poor area in the Eastern mountain slope as 'zona de pastoreo' ('grazing area') villagers were forced to sell their flocks lacking their indispensable land base.

Sheep and goats were the main source of meat for year-round consumption and also generated monetary revenue by periodical sales in markets, particularly to pay 'foros' and land taxes ('contribuição'). Usurpation represented a severe blow for the community during the famine brought by the 1936-1939 Civil War. From the 1950s onward, each house kept no more than five sheep (vs. 30-60), in addition to six cows and oxen, a few feral horses ('bestas' or 'garranos', a breed similar to the Cornish Dartmoor 
Pony) and other house animals such as pigs or donkeys. Today only two of the now five commoner houses still keep sheep for self-consumption. Although cows and feral horses were taken to fields and nearby common land areas that were not planted, the almost total suppression of herbivore pressure in the old mountain pastures together with the introduction of pine monocultures and other measures such as wetland drainage represented a significant change in landscape and a disturbance of existing habitats.

In 1975 villagers initiated the process to reclaim ownership of the commons in spite of strong opposition from the municipality, and legally achieved recognition as a 'monte vizinhal em mão comum' in 1977. State management of communal lands continued until the last ties with the administration were broken in 2002, signalling full community control and self-management. However, the landscape handed over in 2002 had little in common with the one seized by the state 60 years earlier. Pastoralism had virtually stopped with the exception of some feral horses that still roamed around and the land presented deep scars left by tin and tungsten mining, forced drainage of peatlands, introduction of pyrophyte tree species (Eucalyptus sp., Acacia sp., and Pinus sp.), and subsequent waves of forest fires.

In spite of the daunting scenario, Frojám, with just 20 inhabitants, has become an example of how community-based projects can make a difference in restoring biocultural heritage [43-45] and even reformulating hegemonic top-down conservation projects in Western societies [46]. A management plan drafted in 2018 to restore the 'Campo de Lamas' wetland within the enclosed area was selected as one of four pilot case studies in Spain of climate change adaptation of natural management initiatives [15]. Lack of resources to implement restoration work has been met through volunteer initiatives (such as the 'Brigadas deseucaliptizadoras') mobilizing hundreds of individuals to remove invasive exotic tree species and restore native habitats. This has led to swift changes in the landscape moving away from the previously dominant Eucalyptus plantations to a mosaic of recovering natural habitats. Besides being among the first UN acknowledged Indigenous and Community Conserved Areas in Europe, Frojám is also within a Special Landscape Interest Site (LEIP) and has been designated as a Natural Site of Educational Interest. It is also one of the first self-declared 'No-go areas' for mining as part of the community's struggle to end environmentally degrading activities [47].

While the community sustains the return of mountain pastoralism as an aspirational goal that would see the area of the enclosure back to its ancestral use, the 'Campo de Lamas' management plan incorporated a solution conceived by the community itself: 'natural beaconing' or 'biobeaconing'. When the first section of wall (Figure 3) was noticed in 2016 during scrub clearing works, the community decided to place a 3 metre strip at each side of the enclosure followed by a row of Castanea sativa that, being a relatively fast-growing species, would function as a 'barricade tape' to avoid future damage due to mechanical clearing. Chestnut trees (Castanea sativa) also provide cover to control undergrowth that would eventually allow the appreciation of the structure with little or no maintenance. For 'Campo de Lamas', the management plan suggested using Salix atrocinerea and other hydrophilic species already present.

Natural habitats in Frojám have suffered dramatic alterations since the forced abandonment of pastoralist practices in the 1940s. The potential vegetation would be a silicicolous deciduous broad-leaved oak (Quercus robur) forest, with birch (Betula alba), alder buckthorn (Frangula alnus), and willow (Salix atrocinerea) as pre-climax stages. The vegetal formation is in the altitudinal interface of two Galician-North Portuguese oak woodland types, defined by the submontane/montane Vaccinio-Quercetum roboris and the lowland Rusco-Quercetum roboris associations [48]. However, current vegetation is composed of gorse-heath shrubland, degraded pine, and eucalyptus plantations and grassland in a few areas. 

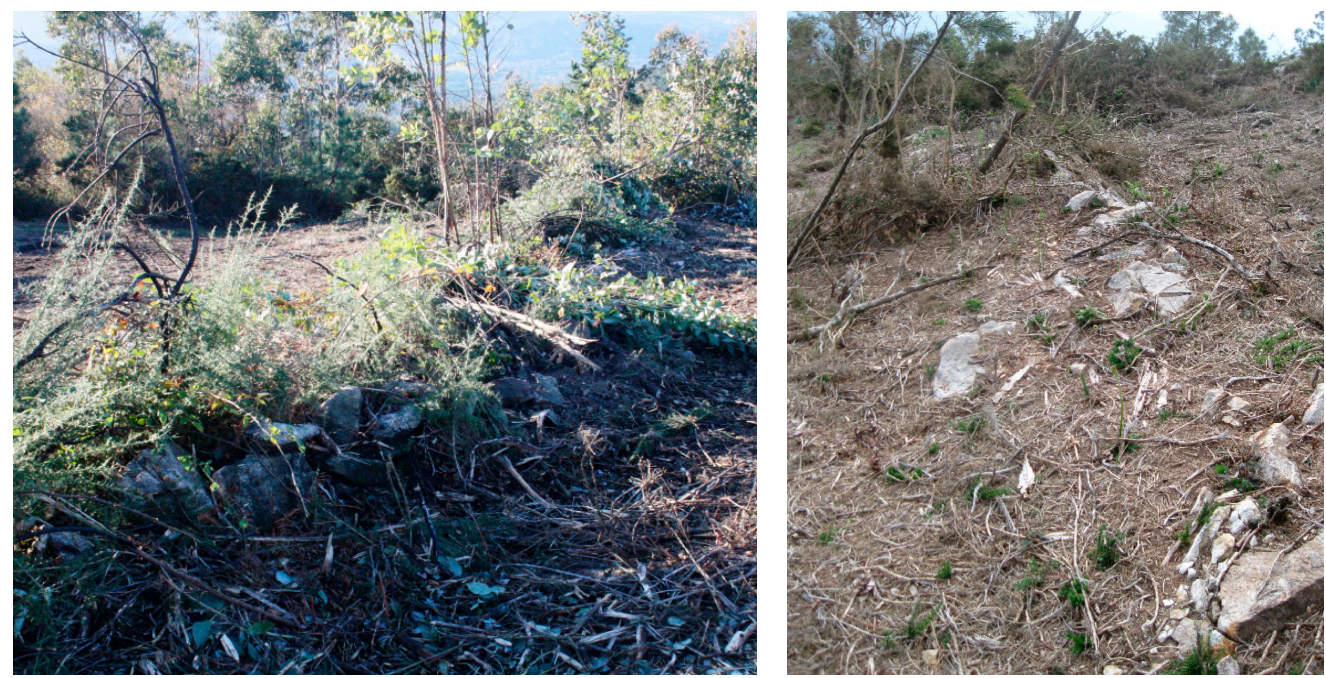

Figure 3. Dry stone sections of the Frojám enclosure (Photographs: Joám Evans Pim).

The whole zone has suffered repeated burns during the last decades $(1975,1993,2000,2006$, and 2016), affecting the productivity of pine and eucalyptus forest plantations. Interestingly, the deeper soils of the enclosure have allowed faster recovery of plantations compared with the more degraded soils in surrounding areas.

Ulex europaeus, Calluna vulgaris, and Erica cinerea are the dominant species in the shrubland, with significant coverage of Erica umbellata in areas with shallower soils. This shrubland vegetation is classified in Annex I of the 92/43/CEE European Habitats Directive [20] as 'European dry heaths', habitat of community interest (code 4030). Other gorse-heath formations occur in the Frojám enclosure, yet restricted to 'Campo de Lamas' peatland, dominated by a different gorse species, the Western gorse (Ulex gallii) and two hygrophilous heath species (Erica ciliaris and Erica tetralix), although Calluna vularis is also abundant. Two subtypes can be identified, with the Western gorse-wet heath community occupying the external parts of the wetland, and purer ericoid formations in the areas with a higher water table. This habitat is classified in Annex I of the 92/43/CEE European Habitats Directive [20] as a priority habitat under the name 'Temperate Atlantic wet heaths with Erica ciliaris and Erica tetralix' (code ${ }^{*} 4020$ ).

Grassland should have occupied the main part of the Frojám enclosure when pastoral practices were active, as images from the 1945-1946 American Series A Photogrammetric flight seem to suggest. As a serial formation, grasslands tend to be replaced by scrub plant communities once grazing and trampling have finished. These practices have been mostly absent in Frojám during the last 70 years, so we expect grassland to be decreasing in the area.

However, two hygrophilous grassland types are currently inside the Frojám enclosure. The most abundant is represented by wet meadows dominated by Molinia caerulea, accompanied by tall-growing herbs, mostly Deschampsia flexuosa and Agrostis hesperica and some rushes and sedges and smaller herbs, and Sphagnum subsecundum. This habitat could be included in the habitat of community interest 'Molinia meadows on calcareous, peaty, or clayey-silt-laden soils (Molinion caeruleae) (code 6410)' in Annex I of the 92/43/CEE European Habitats Directive [20]. Although species-poor Molinia grasslands on acidic soils are generally excluded from the 6410 habitat definition of Annex I, analyses of organic carbon content in the soil of 'Campo de Lamas' identify this wetland as a minerogenic bog with peat accumulation (Serrano et al., unpublished data).

The other community is a hygrophilous species-rich caespitose acidophilous grassland dominated by Agrostis species, including grasses and herbs as Agrostis capillaris, Agrostis curtisii, Agrostis hesperica, Avenula sulcata, Potentilla erecta, Carum verticillatum, Danthonia decumbens, Pseudarrenatherum longifolium, Gentiana pneumonanthe, Serratula tinctorea, Carex binervis, and Galium saxatile, with some presence of Molinia caerulea and Agrostis stolonifera, among others. This type of community has been included in 
the association Galio-Danthonietum decumbentis [19] in the Violion caninae alliance of pasturelands in extremely oceanic environments in the European Atlantic Arc. Thus, the so-called 'Agrostis curtisii grasslands' community [21] from the south-west has been considered ascribable to this alliance [19]. Despite the scarcity of Nardus stricta in these communities, they belong to the Nardetea phytosociological class and consequently have been classified under the priority habitat 'Species-rich Nardus grasslands on siliceous substrates' ( 6230 code) [19].

Wet heaths and Molinia grassland communities appear intermingled in 'Campo de Lamas' in the areas with a higher water table, with the Agrostis hygrophilous grassland occupying some parts of the outer rim of the wetland. Under Frojám environmental conditions, the wet heath vegetal community should prevail in the wetland; however, it covers only $17 \%$ of the area, while Molinia grassland covers $70 \%$ of the area, having the peripheral Agrostis hygrophilous grassland the lesser extent, with 13\% coverage of the wetland remnant.

\subsection{The Ladydown Moor Common as a Case Study in Cornwall}

Situated $9 \mathrm{~km}$ south-east of the north Cornwall coast at Port Isaac Bay, and $5 \mathrm{~km}$ south-west of the regional high point on Bodmin Moor, Ladydown Common (sometimes 'Lady Down', Figure 4) is an area of mixed heathland and 'in-bye' grassland at $233 \mathrm{~m}$ above sea level (30U 3811925601778 , datum WGS84). The area falls within the Cornwall Area of Outstanding Natural Beauty, and comprises approximately 49 ha of common grazing land. It is listed in the national register of Common Lands-entry 124-as part of a larger grouping totalling 162 ha, of which Ladydown forms the south-western tip [49]. The immediate area features a minimum of six stone cairns; some of which appear to be clearance cairns, though at least two are likely to have been sepulchral [50,51]. There are further partially buried remains of a settlement including hut circles and associated field systems, most likely to be late Iron Age in establishment [50].

To the immediate west of the survey area is the village of St. Breward ('St. Bruwerd' in Cornish), which comprises three adjoining linear settlement zones known as Row, Churchtown, and St. Breward; each situated on the upper slope of the Camel river valley, which runs NE-SW to the west of both the village and the moorland zone. St. Breward itself is not listed in the Domesday Book, though the nearby settlements of Blisland and Hamatethy are, indicating continued settlement in the region of the moor. The 2011 national census recorded 919 residents within the parish, which also includes the Hamlet of Fentonadle, which lies around $1 \mathrm{~km}$ to the north-west of Churchtown, within the valley.

Granite extraction has formed the major economic activity in the area for much of the history of the settlement, with the high-quality building stone being exported nationally (including for the construction of London's Tower Bridge and Thames Embankment) [52]. More generally, the area comprised small groups of farmsteads (typically between 5 and 20 ha) of stone-enclosed mixed grazing and arable land with shared commons. The local economy also supported other extraction operations (some predating the industrial period), China Clay quarrying, and coastal fishing.

Population and settlement fluctuations within the area are linked to the operation of these extraction operations and are evidenced by the partially-buried settlement remains on and around the common, and by the patterns of enclosed 'in-bye' field systems without attendant homesteads. Earlier habitation and land use are indicated by the hut circles and megalithic monuments that are found across the area, which include the Fenacre stone circle, five standing marker stones, and a stone cross, of which only the base now remains in place [53]. Further prehistoric features have been recorded at nearby Stannon Quarry, most notably burials dating to the Bronze Age [54].

Significant demographic change took place across the region during the mid-part of the 20th century, driven by international conflict and the mechanization of agriculture and extraction operations. Farming became economically unviable on the traditional small scale and resulted in many landholdings becoming conglomerated into the larger commercial operations more recognisable today. This led to the near abandonment of unproductive or difficult to manage areas in upland zones such as Bodmin Moor, including the adjoining commons of Ladydown (Figure 4) and Emblance Down. 
Whilst industrialised agriculture now envelops the area with post-medieval enclosures of sub-rectangular fields and centralized farmsteads, the isolated nature of the common and proximity to both mineral extraction zones and archaeological features have meant that full encroachment of grassland 'improvement' has been limited. Ladydown Common is therefore a representative area of the at-risk heritage of the characteristic Cornish Killas landscape zone, comprising areas of unimproved grassland and traditional vernacular stone-built livestock and land management structures [55]. It is formed of upland heath (also known as moorland) plant communities, a semi-natural habitat with long histories of seasonal land management with livestock and mixed cropping.

Bodmin Moor as a whole constitutes the most south-westerly upland zone in England and is a key component of both the Cornwall Area of Outstanding Natural Beauty (AONB). The region is included in the Cornish County Conservation Area on account of the mix of cultural and natural heritage preserved within it and is a designated Site of Special Scientific Interest (SSSI) under the Wildlife and Countryside Act of 1981. Ladydown forms a component of this landscape joined to the local peak of Brownwilly Tor (Cornish: Bronn Ewhella) through a series of linear common land links which include the neighbouring Emblance and Treswallock Downs. The grouping falls under the joint protection of the Commons Act (2006), and the Countryside Rights of Way Act (2000) through the mechanism of the Area of Outstanding Natural Beauty designation. In practice this designation enables locals to access grazing areas for livestock in traditional open field management practices despite much of the land now being in private ownership, and also places land management and planning decision-making in the hands of local stakeholders (not exclusively landowners). This dual-level of protection ensures heritage, aesthetic, and habitat conservation measures are given due consideration within any application to build, demolish, or change land-use patterns.

Habitats related to the heritage land use of the Common are reliant on the continued management of landscapes, as the natural climax communities are a mix of Oak-Birch woodland and blanket bog. Within the common itself there are two distinct plant communities linked to former livestock enclosures and land management within the common. Adjacent to the modern stone-walled field enclosures there are the recognizable mix of Bent (Agrostis capillaris) and Rye (Lolium perenne) grasses, with a deep Moss thatch. Away from the recognizable grazing zone, onto the greater area of the Moor, the Grass sward includes Common Cotton (Eriophorum augustifolium) with a predominant coverage of Bent species (Agrostis curtisii, Agrostis capillaris), with Sheep's Fescue (Festuca ovina) and Purple Moor Grass (Molina caerulea) also present. This so-called species-rich 'Agrostis curtisii grasslands' community [21] from south-west Great Britain has been considered ascribable to the Violion caninae phytosociological alliance [19] and therefore to the Nardetea class, what leads to its classification in the priority habitat *6230 [56]. Herbaceous hygrophilous species of the Moor are typical of the upland moorland habitat and include Molinia caerulea, Tormentil (Potentilla erecta), and Heather (Calluna vulgaris), with Common Bramble (Rubus ulmifolius), Hawthorn (Crataegus monogyna), and Blackthorn (Prunus spinosa) at the margins, principally as plant populations on and adjacent to the dry stone walls (whose construction is UNESCO Intangible Cultural Heritage of Humanity since 2018, Figure 5); forming the common 'Cornish Hedge'. This formation dominated by Purple Moor Grass can be included in the Molinia caerulea-Potentilla erecta association [21]. This is a species-poor community that develops on acidic substrates under intensely oceanic climates, and it is not included in Annex I of the Habitat Directive, corresponding to the British National Vegetation Classification (NVC) M25 Molinia caerulea-Pontetilla erecta mire.

The stone enclosures of the study zone are multi-phase in construction and differ in condition and preservation today (Figure 4). The area contains a section of a mixed Cornish hedge and a dry-stone wall (Figure 5) along its north-west edge, forming the boundary to the adjoining modern field systems. This is the best-preserved feature of the area, in excess of 2 metres in height, made of alternating lodged stone in a herringbone pattern, with soil infill and a combination of grasses, moss, and herbaceous plants along its length, including Hawthorn (Crataegus monogyna) and Bramble (Rubus ssp.). Immediately adjacent to the hedge, to the south-eastern side, runs a grassed ditch almost a metre 
deep in places. The lack of terminal outlets for this ditch suggests it is generated by sheltering animals moving along the boundary, and not as a drainage feature.

Within the area of the moor to the south-east of this boundary, there lies partially buried remains of enclosure wall (Figure 6), adjacent to the similarly buried remains of a former settlement [57]. In addition, approximately $200 \mathrm{~m}$ to the north-east of these features are the earthwork remains of a further livestock enclosure of indeterminate age. The extent and nature of these features have not been investigated through excavation, though habitual close grazing has resulted in some areas of both these features becoming exposed. The southernmost linear enclosure feature measures 1 to $1.5 \mathrm{~m}$ in width, but is almost entirely buried, apparent for the most part as a result of the different vegetation that grows over the feature. At no point along its length is the structure any greater than $0.5 \mathrm{~m}$ higher than the ground surface around it. This form is echoed in the adjacent cairns (both clearance and funerary), and the archaeological remains of the former settlement. The northernmost enclosure features are more prominent in the landscape, possibly as a result of its proximity to a modern gateway, where the collection and feeding of cattle take place at times of the year, causing increased erosion of soil around the features. The buried linear feature here is in excess of $2 \mathrm{~m}$ in width near to its NE terminal end and is in excess of $1 \mathrm{~m}$ in height for much of its length. The feature effectively merges with the landform after a length of around $20 \mathrm{~m}$ (running NE-W).

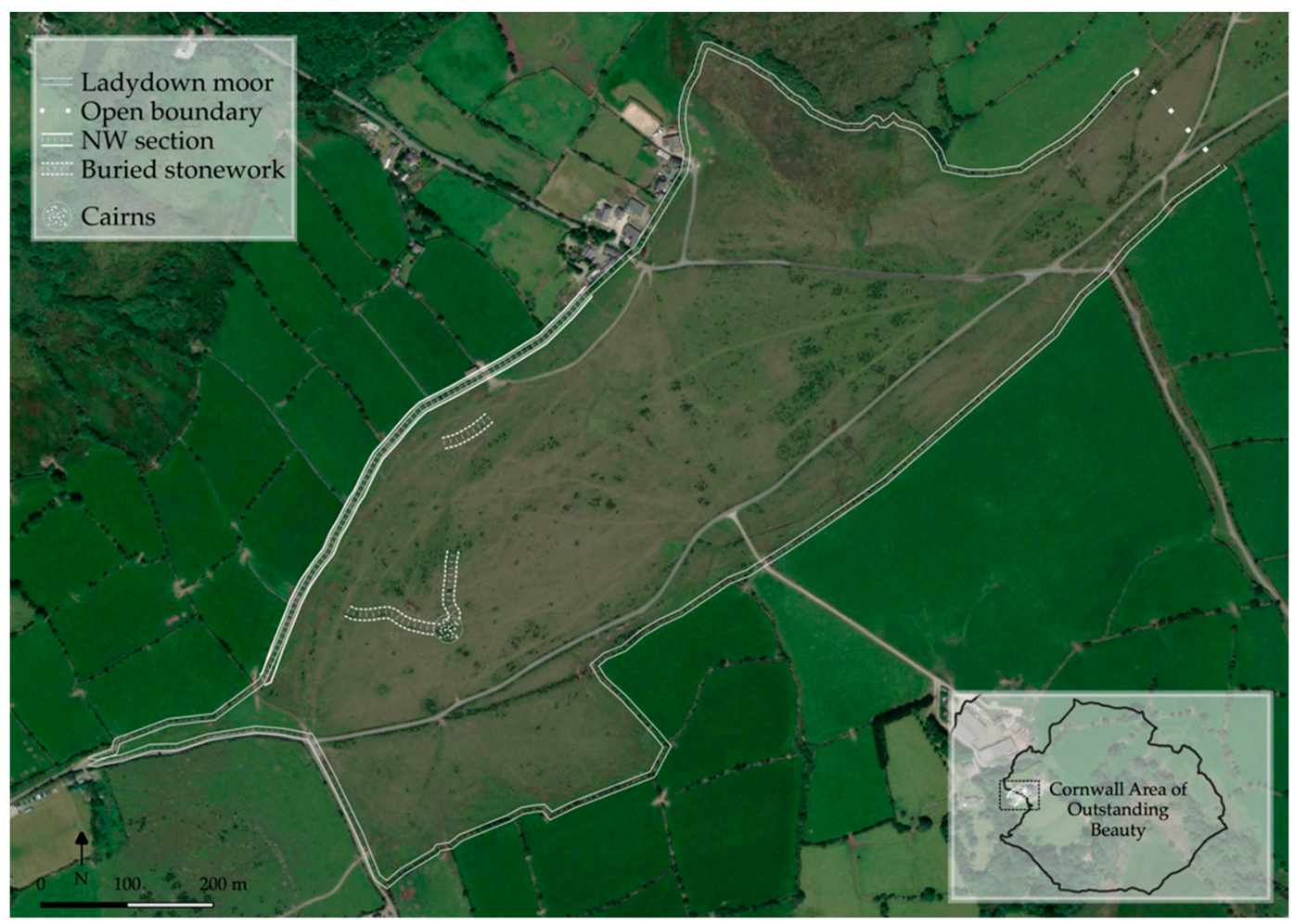

Figure 4. Orthoimage highlighting Ladydown Moor and its introduced structures. Source: ESRI World Imagery (Esri, DigitalGlobe, GeoEye, i-cubed, USDA FSA, USGS, AEX, Getmapping, Aerogrid, IGN, IGP, swisstopo, and the GIS User Community). 


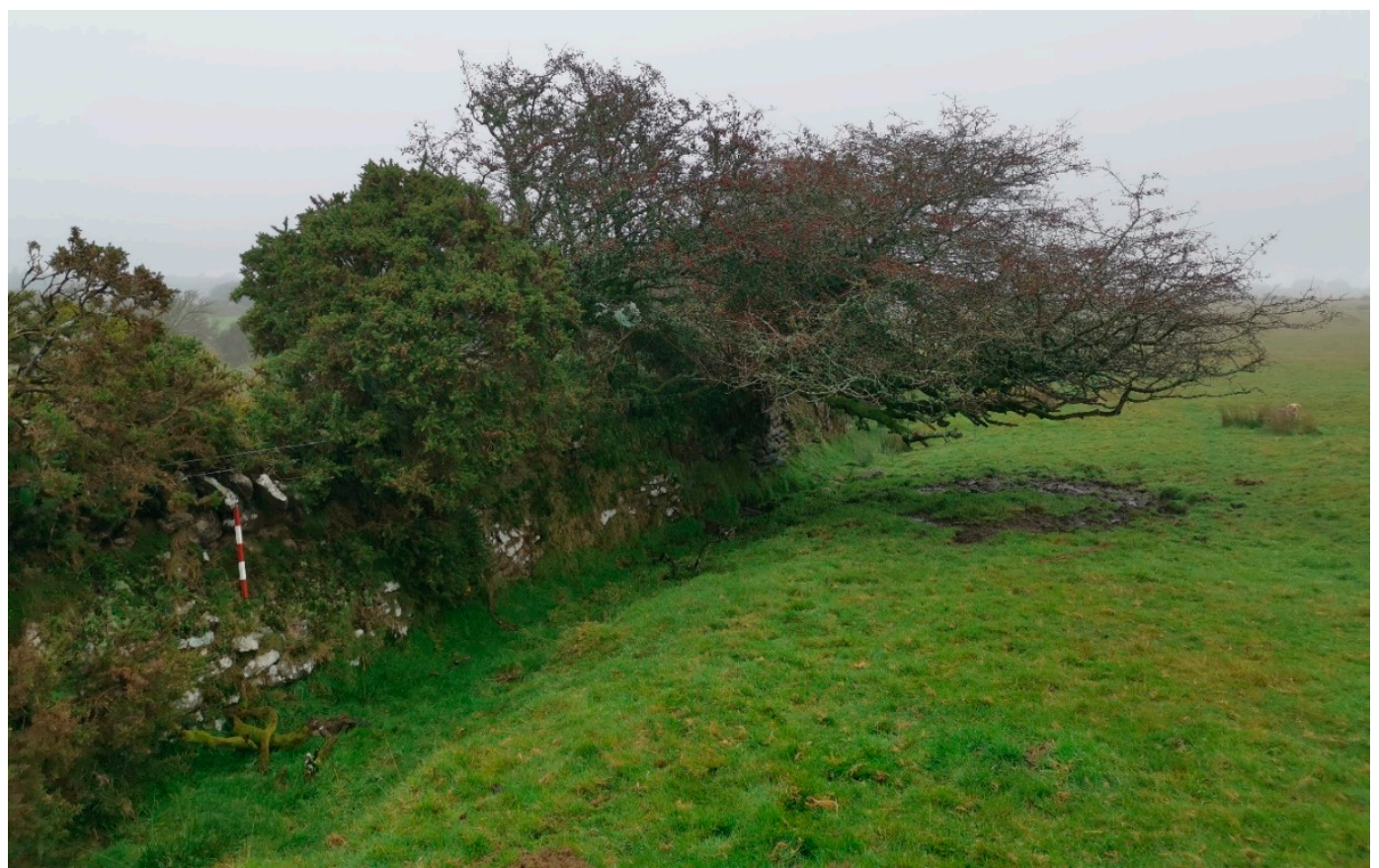

Figure 5. Dry stone sections of the Ladydown Common enclosures, in the form of a traditional Cornish Hedge. Scale $50 \mathrm{~cm}$ (Photograph: Richard Grove).

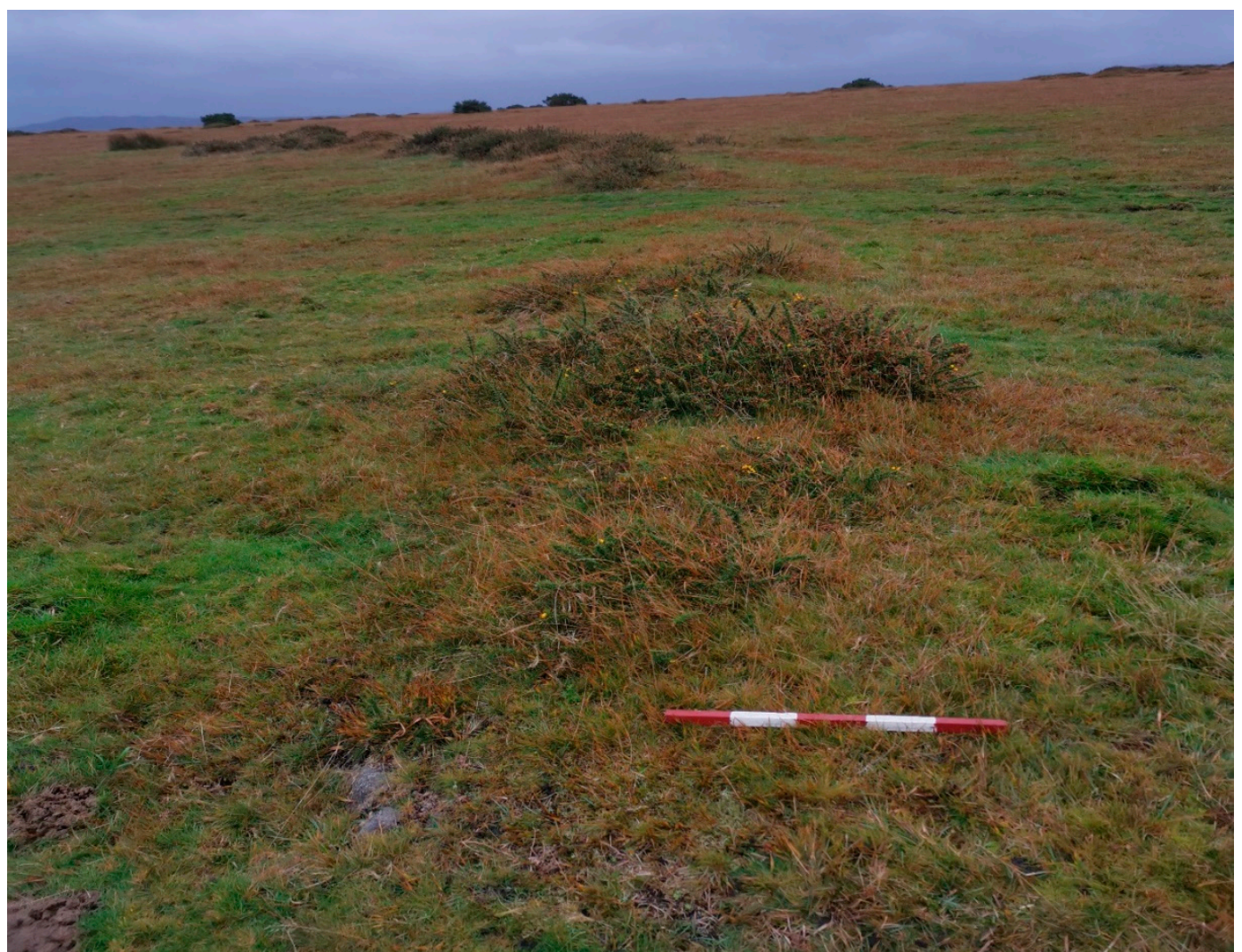

Figure 6. Partially buried stone sections of the Ladydown Common enclosures. Scale $50 \mathrm{~cm}$ (Photograph: Richard Grove). 


\section{Discussion: Biocultural Heritage Manifestations and the Role of Community-Based Conservation}

Frojám and Ladydown enclosure areas share comparable environmental conditions in terms of climatic and edaphic variables. However, they represent different stages regarding the traditional pastoral activities that justified their ancient construction. While Ladydown is still open to grazing, Frojám has suffered a severe process of disturbance of the traditional biocultural environment by drainage and forestry plantations of pyrophyte tree species [15]. Thus, Ladydown has an important coverage of grassland habitats evidencing the long-term continuity of pastoral uses, with a hygrophilous species-rich Agrostis curtissi grassland as a predominant community, in a mosaic with Molinia acid grassland and other hygrophilous formations in the wettest places. The Agrostis curtissi grassland is a hyperoceanic community only occurring in Great Britain in Cornwall, SW England and far South Wales [25], being classified under the priority for European conservation $6320^{*}$ grassland habitat type [19].

Conversely, the absence of pastoralism would have made Frojám unsuitable for the development of grassland habitats, which should have existed in the past. Serial gorse-heath shrubland is expected to predominate under current conditions, with climatic wet heaths of Erica ciliaris, Erica tetralix, and Calluna vulgaris (4020* Habitat directive code) in mosaic with Sphagnum bog in the peaty wetland. Although the grassland representation in Frojám is quite inferior in land coverage than in Ladydown, it is greater than would be expected. The Molinia peaty grassland (6410 Habitat directive code) and Agrostis grassland ( ${ }^{*} 6320$ Habitat directive code) are still found in Frojám, albeit confined to the peaty wetland of 'Campo de Lamas', where the former is overwhelmingly dominant.

This endurance of grassland after decades of grazing interruption can be interpreted as a marker of past traditional practises and, therefore, a manifestation of biocultural heritage [3,4]. Molinia grassland predominance over Erica ciliaris and Erica tetralix wet heaths on acidic/oligotrophic wet environments are interpreted as the result of historical processes, including traditional practices, which increase the soil nutrient content and promote vegetation replacement. Traditional pastoralism produces eutrophication by combining recurrent burning and grazing $[58,59]$. The Atlantic wet heath habitat is extremely dependant on oligotrophic conditions, and organic matter and nutrient changes in soil derived from burning result in substitution by Molinia grassland [60]. The concentration of grazing livestock is a driving factor for increasing soil nitrogen content, eventually leading to the predominance of Molinia grassland over wet heath communities [61]. Once established under conditions of increased nitrogen availability, the competitiveness of Molinia will be kept through efficient mechanisms of nitrogen sequestration [62] that could result in a durable vegetation shift.

In Ladydown, the wet heath community is currently absent, as would be expected under the long-term active pastoral practises. This habitat occurs in nearby areas of Bodmin Moor, although the community is impoverished since Erica ciliaris, an endangered species in Great Britain, shows a gap in its distribution range in the region [17]. In Frojám, the wet heath community shows some recovery, intermingled with the relatively species-poor Molinia grassland. Interestingly, in Frojám remnants of the hyperoceanic hygrophilous species-rich Agrostis grassland of the Nardetea class (habitat directive code *6230) can still be found. This interesting vegetal community is well distributed in other areas with strong grazing pressure in the Barbança mountain range. Under hyperoceanic climate conditions, this community covers the pasture uplands that otherwise would be covered for more dry grasslands [19].

The peaty wetland associated with the Frojám enclosure has worked as an unexpected refuge for this hygrophilous community in the absence of grazing, preserving both the grassland as a biocultural heritage marker and a reservoir for species recovery. In fact, since the activities of environmental restoration initiated in Frojám, this habitat, previously confined to a rim bordering 'Campo de Lamas' wetland, has expanded to cover the surroundings forestall trails. The reasons why the grassland community was not ousted by gorse scrub formation since the abrupt stop in the traditional practices remain unclear, although annual water level oscillations and possible herbivory from wild animals could have had some role favouring grassland habitat resilience. Remnants of habitat heterogeneity 
still existing both in Ladydown and Frojám enclosures represent an opportunity for conservation in the context of reactivating common land practices.

The designation of Frojám as an ICCA has implied, besides the international recognition of such territory and their custodian people, a significant shift in the management of hegemonic protected areas in Europe. Whereas state-driven parks have often marginalised human communities traditionally living and interacting with such spaces [46], the Frojám Commons has reversed this paradigm [47,63] by internally defining restoration projects and conservation goals [6] and thus facilitating the identification and restoration of one stone-built pastoral enclosure among other elements of biocultural heritage. This change links to the idea of non-institutional governance [64] and the higher engagement of local stakeholders in restoration projects in rural areas, which often imply the long-term involvement that is required to effectively address the challenge of certain invasive exotic species (in this case, Eucalyptus and Acacia) and integral landscape restoration.

Around $\frac{1}{4}$ of Galicia's total landmass $\left(29,574 \mathrm{~km}^{2}\right)$ is officially classified as Common Land that belongs to 3300 Common Land Communities (Comunidades de Montes Vecinhais) like Frojám. Commons vary in size from a few to several thousand hectares - the average being around 200 ha-and village commons communities being anywhere from just one or two 'open houses ('casa aberta') -with people living in them-to hundreds or even thousands, the average being around 40 houses. All in all, approximately $15 \%$ of the Galician population lives in commons 'open houses'. While many of these commons are still managed directly by the government that has historically prioritized forest monocultures disregarding conservation and traditional uses, a growing number of self-managed commons in Galicia are giving greater emphasis to the preservation and restoration of biocultural heritage. Five such communities have already been acknowledged as ICCAs by the UN Environmental programme (Frojám, Covelo, Teis, Vilar, and Couso) while many others would likely qualify. In all these cases, communities have implicitly or explicitly assumed a biocultural approach to conservation and have become the main actors in the preservation, restoration and protection of closely interconnected elements natural and cultural heritage (e.g., burial mounds, petroglyphs, water mills, enclosures, and trails).

In England, common land formed a central part of the collectively farmed open field tradition of the medieval period. The rise of absentee landlordism in the immediate post-medieval and reformation years saw large areas enclosed for private grazing, and then relatively few common lands survived the process of 18-19th century land reforms as typified by the parliamentary Enclosure Acts. Today registered Commons (under the 1965 Commons Act) cover approximately 3\% of the landmass in England (some $4000 \mathrm{~km}^{2}$ ). These are often areas of high conservation value, including $40 \%$ of all existing heathland $[65,66]$. The same percentage applies to Cornwall that currently holds approximately $100 \mathrm{~km}^{2}$ of common lands divided across almost 300 units. Most Cornish commons, however, are of relatively small size ( $40 \%$ are under 1 ha) with only 10 Commons larger than 200 ha [67]. As early as 1956, the Natural Conservancy stressed in a report to the Royal Commission on Common Land that commons were "wildlife sanctuaries", "reservoirs for species", "islands of semi-natural vegetation", and "disproportionately rich in examples of plant and animal communities which have largely been eliminated from surrounding localities" [68]. While the separation of formal land ownership and 'rights of common', in contrast with common land communities in Galicia, has sometimes lead to conflict, local communities continue to display "an impressive level of initiative and activity (...) in working to establish and maintain wildlife-rich green spaces in their local environment" [64]. An example of this proactive community conservation can be seen in the Cornwall AONB Peatland Restoration Project, a collaboration between local owners and interest groups with a private water supply company and government agencies, with the aim of halting the loss of biodiversity and habitat within the moor $[5,8]$.

In spite of growing evidence of how indigenous peoples and local communities, through their knowledge and traditional management practices, play an active and effective role in ecosystem restoration, carbon sequestration, and prevention of environmental degradation [67], such groups continue to be considered mostly as passive recipients of restoration work while their cultural practices 
remain ignored in spite of being crucial to the preservation of biocultural heritage $[69,70]$. The findings presented in this article stress the leadership and engagement potential of local communities in bringing about effective conservation initiatives that bridge nature conservation, landscape planning and management, and heritage preservation on the basis of long-term biological and cultural relationships between people and their surroundings. From this point on, it is crucial that these relationships-both historical and contemporary—are studied and understood as drivers for both conservation and change.

\section{Conclusions}

As is shown in these case studies, there is a direct link between historic cultural activities and the establishment and survival of habitats and ecosystems within stone-built heritage structures. Several hygrophilous hyperoceanic grassland habitats, related to current grazing in Ladydown and historical grazing in Frojám, have been identified in both enclosures despite the cessation of pastoral practices in the latter for more than seven decades. Not only do these areas demonstrate the anthropogenic origins for what are often seen as natural habitats by the layperson, but the complex ecosystems within them are also the result of long histories of symbiotic human-livestock-landscape interrelationships. Their conservation relies upon the continuation of these long-established practices.

Taking the example of the Cornish type-site at Ladydown, the chronology for habitation and management extends back to the Iron Age at least, with archaeological deposits demonstrating local activity back to the Bronze Age. The immediate surroundings of Frojám are also home to numerous Neolithic burial mounds-including a tumulus in Frojám itself called 'Casa Velha', 'old house', destroyed during open cast mining operations in the 1940s—similarly indicate continuous habitation for millennia. In both cases, as woodland and mire represent the potential natural successional climax for the zone, early activity must have taken the form of clearance, first of vegetation, then of surface stone, resulting in the creation of cairns that remain in situ today (in Frojám these cairns are called 'meroças', akin to Portuguese 'maroiços'). The unique orography of the enclosed areas in both sites relative to lowland farmlands, coupled with demographic, political, and economic changes in the area over time, led to the preservation of Ladydown Moor and certain parts of the Frojám Commons as outliers of historic habitats in areas of encroaching modernization related to mining, forestry, and industrial agriculture.

Whilst sharing a range of characteristics, the stone enclosures Ladydown and Frojám are divergent in some key aspects with regard to their conservation and management today. The moorland site in Cornwall presents some areas of exceptionally well-preserved stonework in the Cornish Hedge forming the western boundary of the moor, as well as a range of buried and partially-buried ruins within the moor itself. In contrast, Frojám presents a more uniformly ruinous structure, resulting from the woodland plantation and its management. Whilst these differences prevent direct comparison regarding the conservation management and use of the areas discussed here, the link between historic use and existing heritage endures in both the stone structures and their associated habitats, as evidenced by both the built and biological cultural heritage extant today. Whilst this study has sought to draw on a range of source materials to create this study, questions inevitably arise from the drawing of conclusions from incomplete datasets. In addressing these, a more comprehensive study would be advisable which would include palynological assessment of soil cores and geophysical survey. The addition of these tasks would provide a detailed chronology of the plant communities specific to the area, and potentially a record of cultural activity related to the creation and development of stone enclosures.

Author Contributions: First idealization, J.E.P. and P.S.; conceptualization, R.G., J.E.P., M.S., and P.S.; writing-original draft preparation, R.G. and J.E.P.; preparation of maps and images, D.C.; writing-review, R.G., J.E.P., M.S., D.C., H.V., and P.S.; editing, H.V.; supervision, P.S. All authors have read and agreed to the published version of the manuscript.

Funding: Fieldwork in Frojám is being supported by Fundação Montescola and the Frojám Community Conserved Area which in turn are grateful for support received from the European Outdoor Conservation Association. In this framework, this work was partially financial supported by a research contract with Fundação Montescola, entitled: Estudo para o restauro da zona húmida de Campo de Lamas (Frojám, Lousame) (2018-CL065). M.S. and P.S. 
thank the financial support of Xunta de Galicia grants ED431B 2018/36 and ED431C 2018/32. D.C. acknowledges receipt of the PhD scholarship "Programa de axudas á etapa predoutoral" (ref. ED481A-2018/263) financed by the Xunta de Galicia.

Acknowledgments: The authors thank Fundação Montescola and the Frojám Community Conserved Area for their interest in the project, collaboration, and valuable assistance, and Javier Amigo (Universidade de Santiago de Compostela, Spain) for a fruitful discussion regarding habitats.

Conflicts of Interest: The authors declare no conflict of interest.

\section{References}

1. DEFRA. Rural Population and Migration Statistics; HMSO: Richmond, UK, 2019.

2. Scott, K.; Rowe, F.; Pollock, V. Creating the good life? A wellbeing perspective on cultural value in rural development. J. Rural Stud. 2018, 59, 173-182. [CrossRef]

3. Eriksson, O. What is biological cultural heritage and why should we care about it? An example from Swedish rural landscapes and forests. Nat. Conserv. 2018, 28, 1-32. [CrossRef]

4. Lindholm, K.J.; Ekblom, A. A framework for exploring and managing biocultural heritage. Anthropocene 2019, 25, 100195. [CrossRef]

5. Why Indigenous Peoples and Traditional Knowledge Are Vital to Protecting Future Global Biodiversity. Available online: https:/ensia.com/features/indigenous-knowledge-biodiversity/ (accessed on 20 November 2019).

6. Evans Pim, J. Indigenous and Community Conserved Areas (ICCAs) in Galiza: Indigeneity or Peasanthood? In Indigenous Wellbeing and Enterprise: Self-Determination and Sustainable Economic Development; Colbourne, R., Anderson, R., Eds.; Routledge: London, UK, 2019; in press.

7. Has Prince Charles Bought Cornwall's Brown Willy? Royal Is Tipped as New Owner of the County's Highest Point after It Sold for Nearly £3m. Available online: https:/www.dailymail.co.uk/news/article-4409718/ Cornwall-s-highest-point-Brown-Willy-sells-nearly-3m.html (accessed on 19 November 2019).

8. Bodmin Moor Peatlands Restoration. Available online: https://www.cornwall-aonb.gov.uk/bodmin-moorpeatlands-restoration (accessed on 19 November 2019).

9. Whittow, J. Geology and Scenery in Britain; Chapmand and Hall: London, UK, 1992.

10. Vidal Romaní, J.R. Granite geomorphology on Galicia (NW Spain). Cuad. Lab. Xeol. Laxe 1989, 13, 89-163. (In Spanish)

11. Loidi, J. The European Atlantic biogeographic province: Flora, vegetation and historical aspects. Ber. Reinh. Tuxen Ges 2018, 20, 191-204.

12. Rivas-Martínez, S.; Penas, A.; Diaz, T.E. Bioclimatic \& Biogeographic Maps of Europe; University of León: Leon, Spain, 2004; Available online: globalbioclimatics.org/form/maps.htm (accessed on 19 November 2019).

13. Ratcliffe, D.A. A Nature Conservation Review: The Selection of Biological Sites of National Importance to Nature Conservation in Britain; Cambridge University Press: Cambridge, UK, 1977; Volume 1.

14. Rivas-Martínez, S.; Penas, Á.; del Río, S.; Díaz González, T.E.; Rivas-Sáenz, S. Bioclimatology of the Iberian Peninsula and the Balearic Islands. In The Vegetation of the Iberian Peninsula, Plant and Vegetation; Loidi, J., Ed.; Springer: Cham, Switzerland, 2017; Volume 12, pp. 29-80.

15. Serrano, M.; Evans-Pim, J.; Carballeira, R.; Sanmartín, P.; Pereira, J.; Rodríguez-Cao, L.; Rodríguez-Cao, J.; Tubío, X. Campo de Lamas. Plan de gestión y adaptación al cambio climatico' (Capítulo 5.1). In Guía Práctica Cómo Planificar los Proyectos de Custodia para Adaptarse al Cambio Climático en las Regiones Vulnerables de España; Xarxa de Custodia del Territori: Vic, Spain, 2018; pp. 71-146. Available online: http://www.xct.cat/mm/ file/2018/Guia\%20Cambio\%20Climatico\%20y\%20Custodia\%202018.pdf (accessed on 19 November 2019). (In Spanish)

16. Geoghegan, H.; Leyson, C. On climate change and cultural geography: Farming on the Lizard Peninsula, Cornwall, UK. Clim. Chang. 2012, 113, 55-66. [CrossRef]

17. French, C.N.; Murphy, R.J.; Atkinson, M. Flora of Cornwall; Wheal Seton Press: Camborne, UK, 1999.

18. Amigo, J.; Rodríguez-Guitián, M.A.; Pradinho Honrado, J.; Alves, P. The lowlands and midlands of Northwestern Atlantic Iberia. In The Vegetation of the Iberian Peninsula, Plant and Vegetation; Loidi, J., Ed.; Springer: Cham, Switzerland, 2017; Volume 12, pp. 191-250. 
19. Izco, J.; Amigo, J.; Pulgar, Í. Violion caninae grasslands (Nardetea strictae) in the North and North-West of Spain. Acta Bot. Gall. 2009, 156, 437-454. [CrossRef]

20. European Commission. The Interpretation Manual of European Union Habitats-EUR28. 2013. Available online: https://www.ec.europa.eu/environment/nature/legislation/habitatsdirective/docs/Int_Manual_EU28. pdf (accessed on 19 November 2019).

21. Rodwell, J.S. British Plant Communities: Volume 3 Grasslands and Montane Communities; Cambridge University Press: Cambridge, UK, 1992.

22. Chambers, F.M.; McCarroll, J. Palaeoenvironmental evidence for the recent rise of Molinia caerulea: Vital evidence for managers. In Managing Molinia; Meade, R., Ed.; Conference Proceedings; National Trust: Swindon, UK, 2016; pp. 22-27.

23. Souto, M.; Castro, D.; García-Rodeja, E.; Pontevedra-Pombal, X. The Use of Plant Macrofossils for Paleoenvironmental Reconstructions in Southern European Peatlands. Quaternary 2019, 2, 34. [CrossRef]

24. Stähli, M.; Finsinger, W.; Tinner, W.; Allgöwer, B. Wildfire history and fire ecology of the Swiss National Park (Central Alps): New evidence from charcoal, polen and plant macrofossils. Holocene 2006, 16, 805-817. [CrossRef]

25. Averis, B. Plant and Habitats: An Introduction to Common Plants and Their Habitats in Britain and Ireland; Swallowtail Print Ltd.: Norwich, UK, 2013.

26. Chambers, F.M.; Mauquoy, D.; Cloutman, E.W.; Daniell, J.R.G.; Jones, P.S. Recent vegetation history of Drygarn Fawr (Elenydd SSSI), Cambrian Mountains, Wales: Implications for conservation management of degraded blanket mires. Biodivers. Conserv. 2007, 16, 2821-2846. [CrossRef]

27. Rackham, O. The History of the Countryside: The Classic History of Britain's Landscape, Flora and Fauna, 1st ed.; Dent: London, UK, 1993; ISBN 978-0-460-86091-8.

28. Canals, R.M.; San Emeterio, L.; Durán, M.; Múgica, L. Plant-herbivory feedbacks and selective allocation of a toxic metal are behind the stability of degraded covers dominated by Brachypodium pinnatum in acidic soils. Plant Soil 2017, 415, 373-386. [CrossRef]

29. Firbank, L.G.; Smart, S.M.; van de Poll, H.M.; Bunce, R.G.H.; Hill, M.O.; Howard, D.C.; Watkins, J.W.; Stark, G.J Causes of Change in British Vegetation (ECOFACT, Vol. 3); Institute of Terrestrial Ecology, Grange-over-Sands, Institute of Terrestrial Ecology: Norwich, UK, 2000.

30. Brown, I. Beacons in the Landscape: The Hillforts of England and Wales; Oxbow Books: Oxford, UK, 2009.

31. Fowler, P.J. The Farming of Prehistoric Britain; Cambridge University Press: Cambridge, UK, 1981.

32. Carroll, C.; Lang, A. The Iron Age (Chapter 5). In The Handbook of British Archaeology; Adkins, R., Adkins, L., Leitch, V., Eds.; Constable: London, UK, 2008; pp. 94-133.

33. Bradley, R. The Prehistoric Settlement of Britain; Routledge: London, UK, 1978.

34. Cunliffe, B. Iron Age Communities in Britain: An Account of England, Scotland and Wales from the Seventh Century BC Until the Roman Conques; Routledge: London, UK, 2005.

35. Balaam, N.D.; Smith, K.; Wainwright, G.J. The Shaugh Moor Project: Fourth Report-Environment, Conclusions. Proc. Prehist. Soc. 1982, 48, 237-240. [CrossRef]

36. Muir, R. The Lost Villages of Britain; Book Club Associates: London, UK, 1982.

37. Slater, G. The English Peasantry, and the Enclosure of Common Fields; Archibald Constable \& Co.: London, UK, 1907.

38. Barbeito Pose, V.J.; España Fernández, X. Consideracións preliminares sobre o pastoreo tradicional na Serra do Barbanza: Evidencias e estruturas etnográficas. Barban. Anu. Estud. Barban. 2010, 6, 125-137. (In Galician)

39. Barbeito Pose, V.J.; Fábregas Valcarce, R.; Rodríguez Rellán, C.; Blanco Chao, R.; Costa-Casais, M.; Martín Seijo, M.; Paz Camaño, A.; Fariña Costa, A.; Gorgoso López, L. Ocupacións domésticas na serra do Barbanza: Resultados preliminares. Gallaecia Rev. Arqueol. Antig. 2015, 34, 125-128. (In Galician)

40. Barbeito Pose, V.J.; Fábregas Valcarce, R.; Rodríguez Rellán, C.; Fariña Costa, A.; Paz Camaño, A.; López Taboada, M.A.; Suárez Piñeiro, A.M.; Abascal Palazón, J.M.; Fernández Suárez, G.F.; Casado González, G.; et al. Do planalto ás terras baixas: Novas achegas á ocupación da península do Barbanza dende a Prehistoria ata o Medievo. Gallaecia Rev. Arqueol. Antig. 2018, 37, 1-38. (In Galician) [CrossRef]

41. ICCA. Registry Case Studies: Froxán Common Woodlands, Spain. Available online: http://www.iccaregistry. org/en/explore/Spain/Froxan-Common-Woodlands (accessed on 20 November 2019).

42. Rico Boquete, E. El Estado en los montes. Intervención pública y respuestas sociales en torno al manejo de los recursos naturales. Gerónimo Uztariz 2003, 19, 77-96. (In Spanish) 
43. Cidrás, D.; Lois-González, R.C.; Paül, V. Rural Governance against Eucalyptus Expansion in Galicia (NW Iberian Peninsula). Sustainability 2018, 10, 3396. [CrossRef]

44. Copena Rodríguez, D. Montes Veciñais en Man Común e Baldios: Unha análise comparativa das propiedades comunitarias de Galicia e Portugal. Sémata Cienc. Sociais Humanid. 2018, 30, 85-104. (In Galician) [CrossRef]

45. Soto Fernández, D.; Suárez García, R. Transición Socio-Ecológica y Cambio Institucional en las Comunidades Campesinas. El caso de los “Montes Veciñais en Man Común” de Galicia Desde la Década de los Sesenta. In Proceedings of the XVI Congreso de Historia Agraria (SEHA), Santiago de Compostela, Spain, 20-23 June 2018. (In Spanish).

46. Zimmerer, K.S. The Reworking of Conservation Geographies: Nonequilibrium Landscapes and Nature Society Hybrids. Ann. Assoc. Am. Geogr. 2000, 90, 356-369. [CrossRef]

47. Ecologistas en Acción. Report: Speculative Mining in Spain; Ecologistas en Acción: Madrid, Spain, 2019.

48. Amigo, J.; Izco, J.; Guitián, J.; Romero, M.I. Reinterpretación del robledal termófilo galaico-portugués: Rusco aculeati-Quercetum roboris. Lazaroa 1998, 19, 85-98.

49. Database of Registered Common Land in England. Available online: https://www.data.gov.uk/dataset/ 05c61ecc-efa9-4b7f-8fe6-9911afb44e1a/database-of-registered-common-land-in-england (accessed on 21 November 2019).

50. Historic Environment Record 1929, Cornwall and Isles of Scilly Historic Environment Record. Available online: https://www.heritagegateway.org.uk/Gateway/Results_Single.aspx?uid=MCO21135\&resourceID= 1020 (accessed on 8 November 2019).

51. Ordnance Survey. Map of Bodmin Moor; Bodmin, Camelford E Liskeard 109_Explorer 1:25,000 Scale; Ordnance Survey: Southampton, UK, 2015.

52. Methven, D.; Bousfield, D. The De Lank Granite Quarries. In A History of St Breward: The Life of a Moorland Village; Bousfield, P., Ed.; St. Breward History Group: St. Breward, UK, 1988.

53. Langdon, A. Old Cornish Crosses; J. Pollard: Truro, UK, 1896.

54. Jones, A.M. Settlement and Ceremony: Archaeological Investigations at Stannon Down, St Breward Cornwall. Corn. Archaeol. 2008, 43-44, 1-141.

55. Bullock, J. Semi-Natural Grasslands. In UK National Ecosystem Assessment; UK National Ecosystem Assessment Technical Report; UNEP-WCMC: Cambridge, UK, 2011; pp. 161-196.

56. Galvánek, D.; Janák, M. Management of Natura 2000 Habitats. 6230 *Species-Rich Nardus Grasslands; European Commission: Brussels, Belgium, 2008; Available online: https://ec.europa.eu/environment/nature/natura2000/ management/habitats/pdf/6230_Nardus_grasslands.pdf (accessed on 20 November 2019).

57. Heritage Gateway: Lady Down-Prehistoric Field System, Prehistoric Hut Circle Settlement. Available online: https://www.heritagegateway.org.uk/Gateway/Results_Single.aspx?uid=MCO21135\&resourceID= 1020 (accessed on 20 November 2019).

58. Vogels, J. Fire as a restoration tool in the Netherlands. First results from Dutch dune areas indicate potentital pitfalls and possibilities. Int. For. Fire News 2009, 38, 23-35.

59. Squires, V.R.; Dengler, J.; Feng, H.; Huan, L. (Eds.) Grasslands of the World: Diversity, Management and Conservation; CRC Press: Boca Raton, FL, USA, 2018.

60. Bensettiti, F.V.; Boullet, C.; Chavaudret-Laborie, C.; Deniaud, J. (Eds.) Cahiers D'habitats Natura 2000. Connaissance et Gestion des Habitats et des Espèces D'intérêt Communautaire. Tome 4. Habitats Agropastoraux; La Documentation Francaise: Paris, France, 2005. (In French)

61. Hampton, M. Management of Natura 2000 Habitats. 4010 Northern Atlantic Wet Heaths with Erica Tetralix; European Commission: Brussels, Belgium, 2008; Available online: https://www.ec.europa.eu/environment/ nature/natura2000/management/habitats/pdf/4010_Atlantic_wet_heaths.pdf (accessed on 18 November 2019).

62. Friedrich, U.; von Oheimb, G.; Dziedek, C.; Kriebitzsch, W.U.; Selbmann, K.; Härdtle, W. Mechanisms of purple moor-grass (Molinia caerulea) encroachment in dry heathland ecosystems with chronic nitrogen inputs. Environ. Pollut. 2011, 159, 3553-3559. [CrossRef] [PubMed]

63. Sajeva, G.; Borrini-Feyerabend, G.; Niederberger, T. Meanings and More. In Policy Brief of the ICCA Consortium; 2019; p. 7. Available online: https://www.iccaconsortium.org/wp-content/uploads/2019/11/ICCA-BriefingNote-7-Final-for-websites.pdf (accessed on 18 December 2019). 
64. Newing, H. Recognition and Support of ICCAs in England. In Recognising and Supporting Territories and Areas Conserved by Indigenous Peoples and Local Communities: Global Overview and National Case Studies; Kothari, A., Ed.; Technical Series No. 64; Secretariat of the Convention on Biological Diversity, ICCA Consortium, Kalpavriksh, and Natural Justice: Montreal, QC, Canada, 2012.

65. Rodgers, C.P.; Straughton, E.A.; Winchester, A.J.L.; Pieraccini, M. Contested Common Land: Environmental Governance Past and Present; Earthscan: London, UK, 2011.

66. Short, C. The traditional commons of England and Wales in the twenty-first century: Meeting new and old challenges. Int. J. Commons 2008, 2, 192-221. [CrossRef]

67. Aitchison, J.; Crowther, K.; Ashby, M.; Redgrave, L. The Common Lands of Cornwall: A Biological Survey; Cornwall County Council: Truru, UK, 2002.

68. Aitchinson, J.; Medcalf, K. Common Land and Conservation. Biological Surveys in England and Wales-A Synthesis; English Nature Research Report; English Nature: Peterborough, UK, 1994; Volume 77.

69. Reyes-García, V.; Fernández-Llamazares, A.; McElwee, P.; Molnár, Z.; Öllerer, K.; Sarah, J.; Wilson, S.J.; Brondizio, E.S. The contributions of Indigenous Peoples and local communities to ecological restoration. Restor. Ecol. 2019, 27, 3-8. [CrossRef]

70. Wehi, P.M.; Lord, J.M. Importance of including cultural practices in ecological restoration. Conserv. Biol. 2017, 31, 1109-1118. [CrossRef]

(C) 2020 by the authors. Licensee MDPI, Basel, Switzerland. This article is an open access article distributed under the terms and conditions of the Creative Commons Attribution (CC BY) license (http://creativecommons.org/licenses/by/4.0/). 